\title{
Work motivation in Project Management: Are we still interested? A bibliometric analysis of doctoral dissertations
}

\author{
Ravikiran Dwivedula ${ }^{1}$ \\ ${ }^{1}$ Assistant Professor, Faculty of Arts-Department of Business Brandon University, MB, \\ Canada.
}

ARTICLE INFO

Keywords:

\begin{abstract}
This study included a review and bibliometric analysis of doctoral dissertations on work motivation in project management. Designed to be an exploratory review, work motivation in project-based organizations, and in permanent organizations which undertake projects were considered. 840 doctoral theses from the period 19722018 were analyzed. The results showed an increasing number of theses being published on the topic of work motivation, and increasingly on allied topics of leadership, job satisfaction, and project management context. Further, a substantial number of these studies are grounded in phenomenology and grounded theoryadopting interviews as a choice of methodology. Empirical studies were also found to be popular, especially in the early decades. Implications for further studies on the topic of work motivation is presented.
\end{abstract}

\section{Introduction}

Research in project-human resource management has generated considerable interest in the recent past (Müller \& Turner, 2010), some of which focused on understanding work motivation (Sieler, Lent, Pinkowska, Pinazza, 2012; Ayokunle, Xia, Hon, \& Darko, 2017). However, the literature may have fallen short in considering the role of context to explain work motivation. The extant literature has focused on investigating work motivation in stable contexts such as a permanent organization (Parker, Broeck, \& Holman, 2017) and the theories of work motivation in such stable contexts have been extended to the field of project management. However, modern organizations operate in contexts of high uncertainty (Alotaibi, \& Mafimisebi, 2016), and nontraditional working relationships such as a network of actors working with each other for a limited time to achieve specific objectives (Johnson, Creasy, \& Fan, 2016). Such organizations are characterized by projects that span across the functional units and being managed as a network, having multiple or divergent objectives and knowledge-based work processes (Lindner, \& Wald, 2010); what are known as pluralistic contexts (Bredillet,2004). It then becomes important to understand, and establish a theoretical corpus of work motivation specific to such contexts. 
Extant research on work motivation shows a growing interest reflected through a number of papers being published on this topic. An analysis of peer reviewed articles from Web of Science database indicates 145 peer reviewed articles. Allied variables such as leadership, job satisfaction, and project team management have been investigated as an outcome of work motivation. Thus, considering such sustained interest in the topic, the larger purpose of this paper is to investigate whether this interest is reflected in the doctoral studies.

Thus, I set out to investigate the following research questions:

1. What are the countries and leading institutions where research on this topic is conducted?

2. What are the trends in methodologies applied to investigate the research problems?

3. What are the most frequently used key words and how are they associated with each other?

\section{Literature review}

There have been numerous reviews on the constructs and conceptualization of work motivation, research progress, and directions for future research on the topic (c.f. Cerasoli, Nicklin, \& Ford, 2014; Ryan, 2011; Kanfer, 2010; Steers, Mowday\& Shapiro, 2004; Hardré, 2003). Literature reviews on work motivation specific to certain industries can also be found (c.f. Toode, Routasalo, \& Suominen, 2011; Beecham, Baddoo, Hall, Robinson \& Sharp, 2008). Recent works from organizational behavior, and industrial-organizational psychology literature focus on consequences of work motivation such as employee's turnover intent (Sahir, Phulpoto,\& UzZaman, 2018), goal achievement (Janke, Daumiller, \& Dickhäuser,, 2018)antecedents of work motivation (c.f.Thy-Jensen.\& Ladegaard-Bro, 2018), and development of work motivation scale (c.f. Gagné et.al, 2015; Chen \& Fouad, 2016).

There has been growing interest on what motivates project workers recently. Although the state of research is predominantly normative (connoting to practices), literature review reveals these practices connote to major theories of work motivation. Various theoretical lenses such as SocioTechnical Perspective (c.f. Schmidt \&Adams, 2008), scientific management (c.f. Rose \& Manley, 2008), job characteristic model (c.f. Mahoney, \& Lederer, 2006; Beecham, Baddoo, Hall, Robinson, \& Sharp, 2008; Bjorklund, 2010), and intrinsic motivation perspective have been used to explain work motivation in projects and/or project-based organizations (Dwivedula, Bredillet, \& Müller, 2018).

The literature on work motivation in temporary organizations, though 'sporadic' in terms of not being able to offer integrative underlying theoretical lenses to explain motivating job characteristics, has been fairly extensive. Various facets of job such as financial incentives linked to performance (c.f. Rose \& Manley, 2009; Armstrong, 2003, grounded in Scientific Management studies (Taylor, 1911), task identity, task meaningfulness, and feedback on performance (c.f. Schmid \& Adams, 2008; Andersen, 2010 drawn from Tavistock Studies on Socio-Technical Systems perspective (Trist \& Bamforth, 1951; Cherns, 1976; Walker \& Guest, 1952), task variety (c.f. Seiler, Lent, Pinkowska, \& Pinazza, 2012; Heimgartner, Windl, \& Solanki, 2011, grounded in Socio-Technical Perspective (Walker \& Guest, 1952), work as intrinsically motivating, and job security as extrinsic motivator (c.f. Parker, Wall, \& Cordery, 2001; Mahoney \& Lederer, 2006; Schmid \& Adams, 2008, drawn from Herzberg, Mausner, \& Snyderman's Two-Factor theory (1959), task significance (c.f. Badir, Buchel, \& Tucci, 2012; Schmid \& Adams, 2008 drawn from studies on job enrichment (Paul, Robertson, \& Herzberg, 1969; Paul, \& Robertson, 1970), skill variety, and task identity (Mahoney \& Lederer, 2006; Kluger \& DeNisi, 1996; Ling \& Loo, 2015), autonomy at work (c.f. Siler, Lent, Pinkowska, \& Pinazza, 2011; Leung, Chan, \& Dongyu, 2011, 
drawn from Demand Control Model (Karasek, 1979), personal growth and job enrichment (c.f. Li, Bingham, \& Umphress, 2007 grounded in Naylor, Pritchard, \& Ilgen's Resource Allocation Perspective, 1980), communication and collegiality between the project actors (c.f. Kluger \& DeNisi, 1996; Beecham, Baddoo, Hall, Robinson, \& Sharp, 2008; Nesheim, \& Smith, 2015, grounded in Distal motivation theory (Kanfer, 1990; Campbell, 1990), and access to work related information, and informal communication among project actors (c.f. Turner \& Lloyd-Walker, 2008; drawn from Morgeson \& Humphrey's Extended Job Characteristic Model (2006; also see Dwivedula, Bredillet, \& Müller, 2018).

While extant research contributed to our understanding of work motivation in case of projects, there are no reviews available on doctoral studies that focus on work motivation in this knowledge domain.

\section{Methods}

In the present study, a bibliometric analysis was run on the doctoral dissertations conducted on work motivation in project management. PROQUEST Dissertations and Theses Global database was used. The database is extensive and has a collection of all masters and doctoral theses published in social sciences, humanities, computer science, theoretical sciences, applied sciences, and religion. While reviewing the literature, I have applied the following criteria to include the thesis in the sample:

1. The thesis should be included in PROQUEST Dissertations and Theses Global database

2. The thesis is a doctoral dissertation

3. 'work motivation' is one of the variables investigated in the study

4. The thesis is written in English.

An initial search using the key words "motivation" AND "project management" revealed 18,116 documents. The search was further refined by applying the following words as filters based on which the theses are indexed in the database: "work motivation", "motivation", and "project management". 845 documents were then extracted out of which 5 were found not to satisfy one of the above-mentioned criteria- work motivation not being one of the variables that was investigated. Thus, 840 documents were considered for bibliometic analysis. The dates of publication ranged from 1972 to 2018.

\section{Analysis}

VosViewer 1.6.8, an open source software tool used for constructing and visualizing bibliometric networks. The key words are extracted from the thesis' abstract and the title. Words are counted for their presence or absence in the document, what is termed as binary counting. Each word would have to appear for a minimum of ten times to be included in the dataset for analysis. An initial set for 596 terms were first extracted after the first iteration. A relevance score for each of these terms is calculated and $60 \%$ of the terms with the highest relevant scores are considered for the initial iteration of the analysis. Thus, 358 terms were considered for the second iteration.

\section{Results}

In response to question 1, I found that most of the doctoral dissertations are published in USA $(n=761)$. This is followed by England $(n=39)$, Canada $(n=19)$, and other Asian countries. Figure 1 
below summarizes the number of theses by the country.

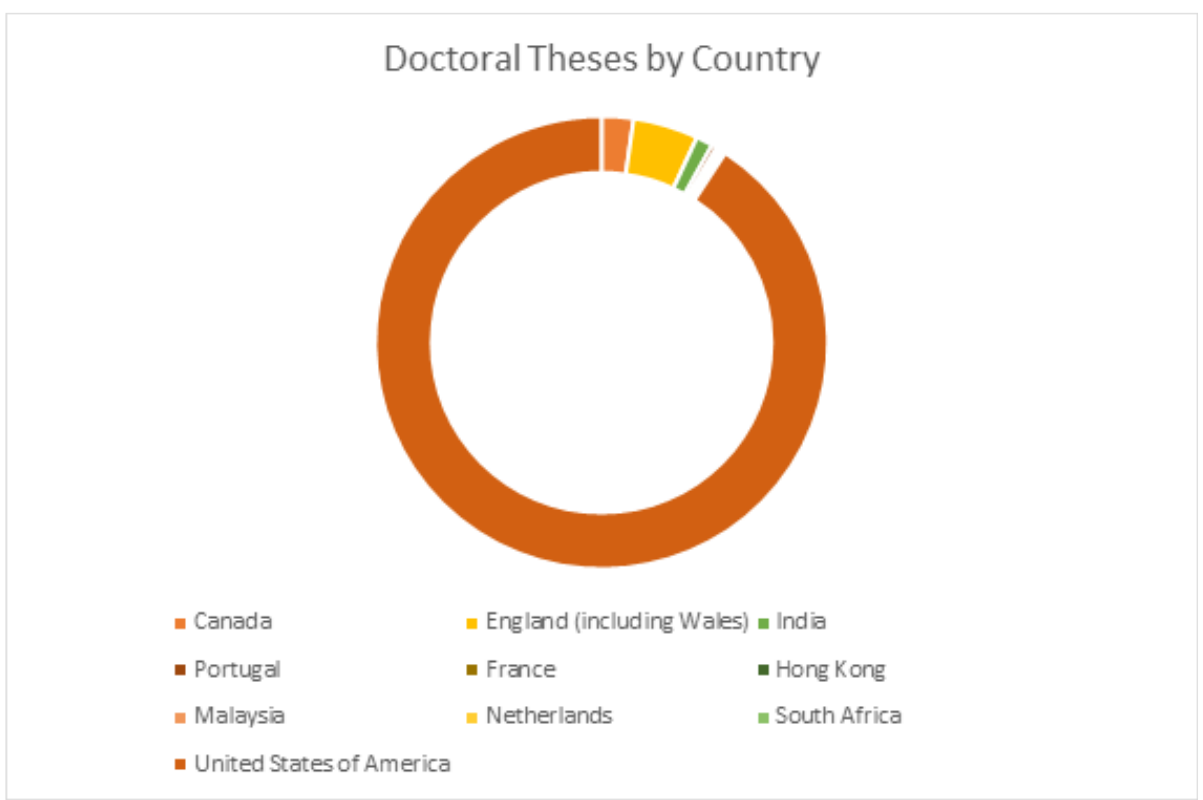

Figure 1. Doctoral theses by country

In response to research question number 2, management as a subject area published the greatest number of doctoral dissertations $(\mathrm{n}=430)$, which was followed by organizational psychology $(\mathrm{n}=182)$, organizational behavior $(\mathrm{n}=182)$, business administration $(\mathrm{n}=116)$, and a significant number in higher education $(\mathrm{n}=84)$.

On the question on methodological trend, I identified four common classes of research methods- quantitative (including survey analysis and ex post facto survey research), qualitative (including depth interviews, focus groups, case research methods, quasi-experimental design that included interviews, content analysis, document analysis, grounded theory, semi-structured interviews), action research (that included computer based simulations, laboratory experiments, and personal observation), and mixed research methods (which includes a combination of any of the afore mentioned research methods). A majority of the theses applied quantitative research methods $(n=424)$. Qualitative research methods $(n=237)$ and action research $(n=40)$ were particularly found to be more common after the year 2000. Likewise, studies employed mixed research methods $(n=139)$ gained acceptance at the turn of the century.

Figure 2 shows the trend in the number of doctoral dissertations by the year for the period 1972-2018. Figure 3 presents the methodology used in the studies from 1972 to 2018. 


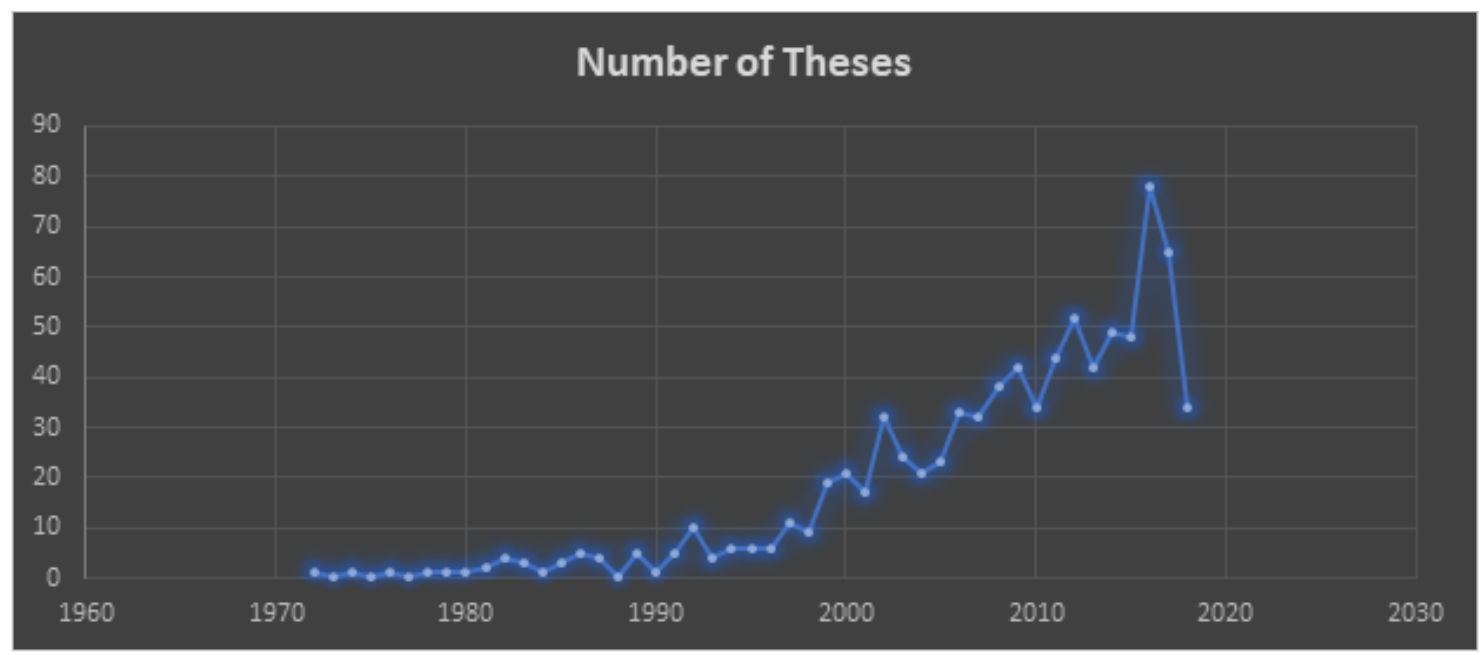

Figure 2. Number of doctoral theses

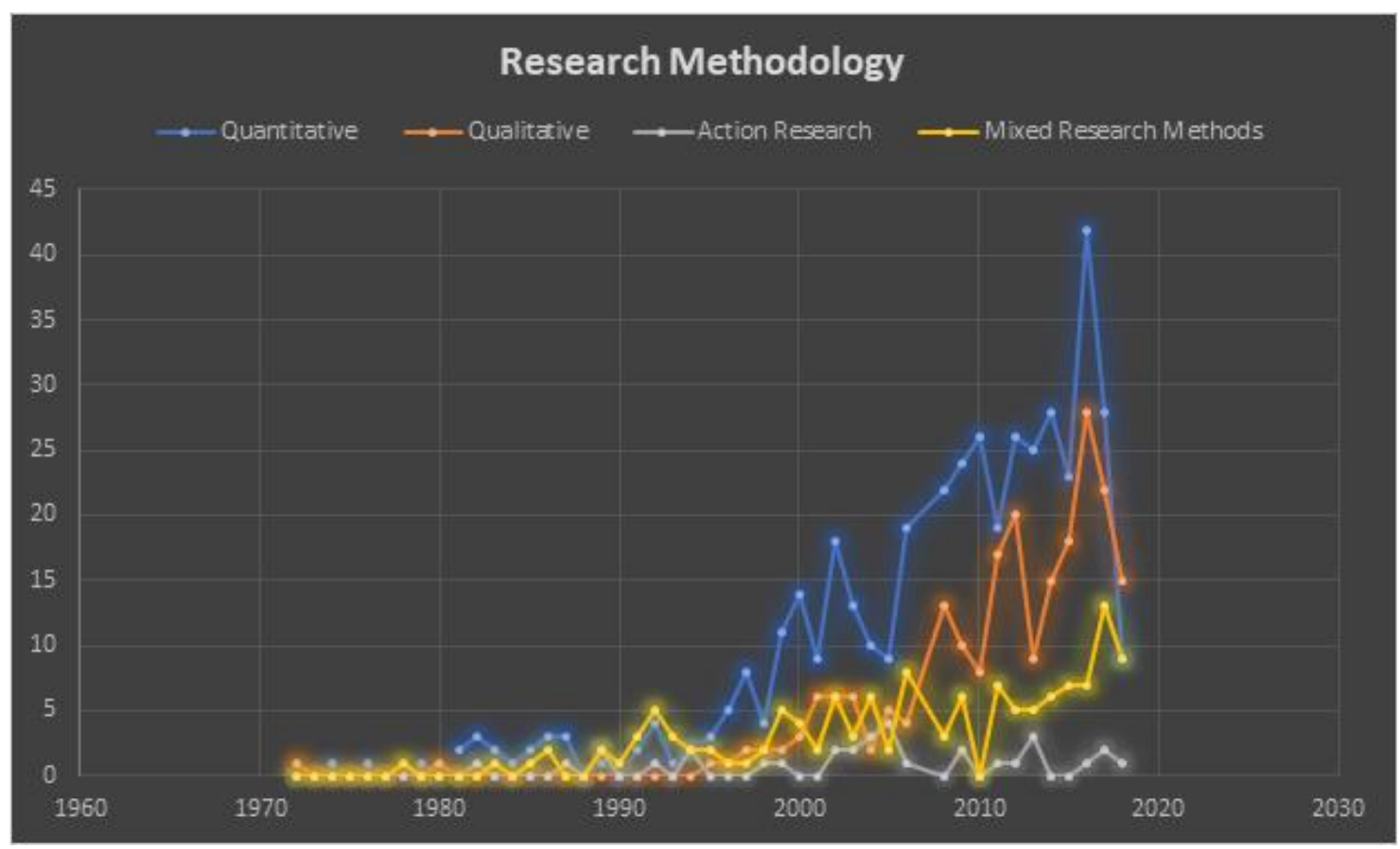

Figure 3. Research methodology applied in the doctoral studies 


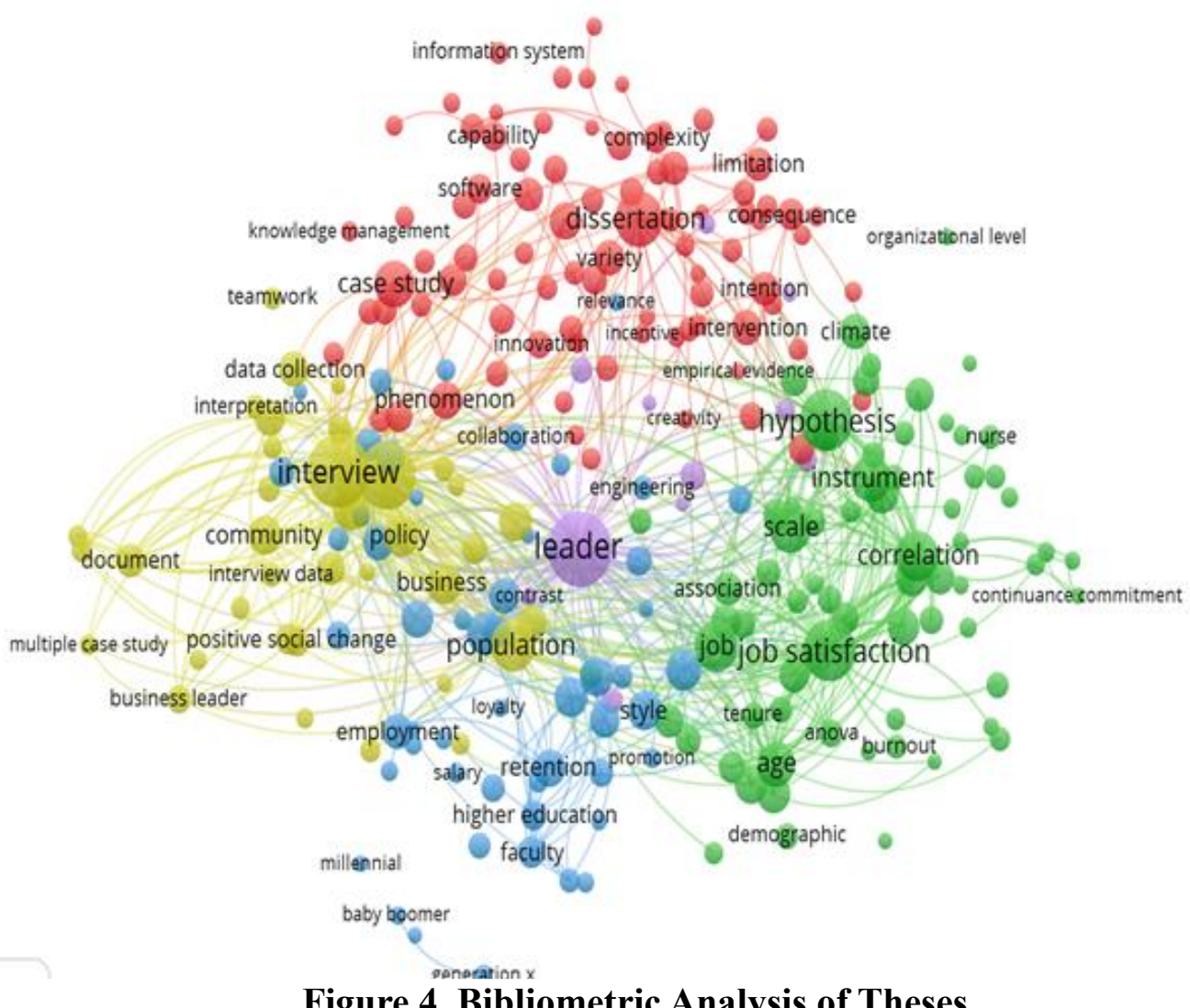

Figure 4. Bibliometric Analysis of Theses

Key word association based on the number of times the words occurred in the corpus was run. It revealed 5 major key words that formed where the other key words gravitated towards each of this one major key word based on the strength of association. Cluster 1-Leader comprised 85 terms of which most significant were- leadership style, incentive, and engineering.

Cluster 2-Interview comprised of 70 terms, most prominent of which were- data collection, multiple case study, interview data, community, and business.

Cluster 3-Job satisfaction comprised of 53 terms, most prominent of which were-climate, tenure, age, burnout, ANOVA, scale, instrument, and hypothesis

Cluster 4-Dissertation comprised of 36 terms, most prominent of which were-information system complexity, knowledge management, and case study

Cluster 5-faculty comprising of 11 terms, most prominent of which were- higher education, retention, salary, and employment

\section{Results}

\section{Response to Research Question 1}

A close to $90 \%$ of the doctoral dissertations considered for this study were published in United States of America (c.f. Bundschuh, 2018; Ricotta, 2018) A distant second and third are England (c.f. Aseri, 2015) and Canada (c.f. Perreira, 2016). With strong project management associations based in USA and with dedicated project management departments in major universities across the country, the number of doctoral studies reflects the growing interest of project management in academia along with the industry. The database does not include the doctoral dissertations from 
Australia and New Zealand. However, I believe the number of publications is still indicative of growing interest in project management scholarship in North America

\section{Response to Research Question 2}

For the period between 1972 and 1990, quantitative research methods were predominantly employed over qualitative research methods (c.f. Wagner, 1974; Almohawis,1986; Stewart, 1980) Most common was survey method and ex-post facto empirical research. A limited number of studies applied qualitative research methods- content analysis (c.f. Meell, 1985; Hensler, 1987). A few studies employed mixed research methods- substantiating the results of empirical survey with document analysis, interviews (semi-structured, depth), and case research method. In the ensuing decade between 1990 and 1999 (c.f. Davis, 1995; Wheeler, 1999), similar trends are observed for the preferred choice of research methodology. However, mixed research methods have gained popularity with techniques such as ethnography and content analysis used in addition to empirical studies. Studies that applied action research methods- quasi-experimental design, personal experience, and computer-based simulations were also used (Cornella, 1992; Tankoonsombut, 1998). The increasing interest on the topic of work motivation continued with a sharp increase in the number of dissertations published. In each of the years that followed from 2001 to 2018, close to $50 \%$ of the dissertations used quantitative research (c.f.Hernick 2017), while mixed research methods, qualitative research using grounded theory (Boggess-de Bruin,2017; Sasala, 2014), thematic analysis (Smith, 2012), semi-structured interview and, narrative approaches (Collins, 2016) are published.

\section{Response to RQ 3}

The bibliometric analysis of the dissertations based on the strength of association among the key words revealed five major word clusters; three of which pertained to allied variables of work motivation, and two related to methodology.

Cluster 1. Leadership: Leadership emerged as a central concept in the studies on work motivation in project management. Indeed this is not surprising as extant literature investigates motivation from the project manager's perspective (c.f. Schmid \& Adams, 2008; Creasy \& Anantatmula,2013). Doctoral studies specifically investigated the leadership style of project managers for their impact on job satisfaction and employee motivation (Agboli, 2016), leader's motivation strategies to improve follower performance (Schwartz, 2013), and the influence of leader on virtual team member motivation in new product development projects (Moore, 2007). Furthermore, leadership as a variable is also strongly associated with variables in other clusters such as job satisfaction (Mirza, 2005), and higher education (Evans, 2000). Both qualitative and quantitative research methods were employed when investigating work motivation from the leader's perspective. Interviews (c.f.Hernick, 2017, Brown, 2002), case research (c.f. Prior, 2015; Kea, 2008) and empirical surveys (c.f. Dunbar, 2002)were the more common research methods.

Cluster 2. Interview. This word cluster mostly comprised of terms related to qualitative research methods employed in the studies. Terms such as multiple case studies, data collection, document analysis and interpretation closely aligned with each other in this cluster (c.f. Apfel, 2011; Pitron, 2008; Boggess-de Bruin, 2017).Apart from methodology, variables related to the larger business context in which the project operates are also a part of this cluster. Thus, studies on positive social change (Williams, 2017), employment and employer expectations (Hillerbrand, 2014; Gallaway, 
2015), and role business leadership and senior management in motivating the employees (Willis, 2001).

Cluster 3. Dissertation. The third cluster includes terms closely associated with project management and projects. Thus, doctoral studies which focused on motivation among information system professionals (Chiu, 2005; Bowen, 2016), project complexity (Frahm, 2015), project innovation, and team member capability (Tonial, 2009), and knowledge management (Steenkamp, 2014; Evans, 2018). These variables affect motivation by influencing the job attitudes of a person.

Cluster 4. Job satisfaction: This cluster comprises of terms mostly associated with outcomes of work motivation, or control and mediating variables in an empirical model that explains work motivation. Thus, doctoral theses on job satisfaction (Hernick, 2017; Holden, 2002), burnout (Emelander, 2011; Whistler, 2014), and organizational commitment (Chiu, 2005). Most of the dissertations on these topics have employed quantitative research methods as is evident from the terms - hypothesis, correlation, ANOVA, and scale being in this cluster (c.f. Dunbar, 2002; Tonial, 2009; Moody, 2008).

Cluster 5. Faculty. A significant number of theses have been published in the area of higher education, and on motivation of faculty in higher education institutions. Variables such as employment, salary, loyalty, higher education, and retention aligned closely with each other. Furthermore, the dissertations employed qualitative research methods more commonly over quantitative research methods (c.f.Brown, 2016; Dunbar, 2017; Jaffee, 2015).

\section{Limitations and Strengths}

Within the scope of this study, the dissertations were considered from ProQuest Dissertations and Theses Global. Therefore, the dissertations from other databases were not considered. The study is significant because it focuses on analyzing the content of doctoral dissertations, which is a good indicator of the sustained interest to study work motivation.

\section{Future research}

There is an ongoing dialog in the project management literature about the conceptualization of a project. At the heart of this conversation is the concept of 'temporary organizing-a currently held view of a project. Temporary organizing is a 'process' when the actors are temporarily engaged or employed and interact with temporary structures such as tasks or resources. The actors will reflect on the nature of interactions. However, the actors may not completely control the process, and the outcomes of this interaction may lead to some other unintended sequence of processes (Bakker et al, 2016). Our review of work motivation literature from the dissertations does not adequately consider this conceptualization of a project. The construct of work motivation, and the theories on which these concepts are built still connote to a stable environment with permanent structures and well-defined tasks; what has been espoused by the traditional view of a project. Therefore, my future research will focus on (i). refining the context-from the traditional view of a project to temporary organizing; and (ii). understanding the influence of this context on the dynamics of work motivation. 


\section{Conclusion}

A general approach to visualize the research on work motivation in project management field has been presented. Based on an extensive literature review of doctoral dissertations from PROQUEST Dissertations and Theses Global database, major themes and the interaction between them was presented. Also discussed was the change in the choice of methodology employed across the years and the countries where research on work motivation is being rigorously pursued. Directions for future research, and implications for doctoral studies on work motivation are presented.

\section{References}

Agboli Chukwura, F. (2016). The impact of selected leadership styles and behaviors on employee motivation and job satisfaction (Order No. 10262875). Available from ProQuest Dissertations \& Theses Global. (1908477734). Retrieved from https://search-proquestcom.berlioz.brandonu.ca/docview/1908477734?accountid=9705

Almohawis, S. A. (1986). Motivation Of Construction Workers In Saudi Arabia: An Expectancy Theory Approach (Order No. 8700162). Available from ProQuest Dissertations \& Theses Global. (303527055). Retrieved from https://search-proquestcom.berlioz.brandonu.ca/docview/303527055?accountid=9705

Alotaibi,A.B., \& Mafimisebi,O.P. (2016). Project Management Practice: Redefining Theoretical Challenges in the 21st Century. Journal of Economics and Sustainable Development, 7(1): 93-99

Andersen J. (2010). An Empirical Study of Design Management Practices in Collaborative design and Construction Projects- The roles, activities, and conceptions of design management across project stages, and within the building. Civil, and Process sectors of a construction company. PhD Thesis-School of Engineering, University of Queensland

Apfel, J. C. (2011). Understanding motivations of sector switchers: Towards a holistic approach to public service motivation theory (Order No. 3460701). Available from ProQuest Dissertations \& Theses Global. (878706066). Retrieved from https://search-proquestcom.berlioz.brandonu.ca/docview/878706066?accountid $=9705$

Aseri, M. (2015). Leadership: A study of global and cultural context in Saudi Arabian organisations (Order No. 10083389). Available from ProQuest Dissertations \& Theses Global. (1779542606). Retrieved from https://search-proquestcom.berlioz.brandonu.ca/docview/1779542606?accountid=9705

Ayokunle,O.O., Xia,B., Hon,C., \& Darko,A. (2017). Effect of motivation and owner commitment on delivery performance of green building projects. Journal of Construction Engineering. 143(9). DOI. 10.1061/(ASCE)CO.1943-7862.0001363

Badir, Y.F., Buechel, B., \& Tucci, C.L. (2012). A conceptual framework of the impact of NPD project team and leader empowerment on communication and performance: An alliance context. International journal of project management. 30, 914-926, https://doi:10.1016/j.ijproman.2012.01.013

Bakker, R.M., DeFillippi, R.J., Schwab, A., Sydow, J. (2016). Temporary Organizing: Promises, processes, and problems. Organization Studies, 37(12): 17031719,http://dx.doi.org/10.1177/0170840616655982.

Beecham,S., Baddoo,N., Hall,T., Robinson,H.,\& Sharp,H. (2008). Motivation in software engineering: a systematic literature review. Information and Software Technology, 50(9- 
10), 860-878, DOI: 10.1016/j.infsof.2007.09.004

Boggess-de Bruin, K. E. (2017). Managers' experiences in motivating multigenerational workforces: Grounded theory (Order No. 10600546). Available from ProQuest Dissertations \& Theses Global. (1936390667). Retrieved from https://search-proquest com.berlioz.brandonu.ca/docview/1936390667?accountid=9705

Bowen, A. (2016). Factors leading to motivational decline among team members and the impact of motivational decline on project success (Order No. 10107693). Available from ProQuest Dissertations \& Theses Global. (1793406805). Retrieved from https://searchproquest-com.berlioz.brandonu.ca/docview/1793406805? accountid=9705

Bredillet, C.N. (2004)., Understanding the very nature of Project Management: a praxeological approach. Paper presented at the 2004 PMI Research Conference: Innovations, July, London, UK

Brown, A. D. (2016). Corporatized higher education: A quantitative study examining faculty motivation using self-determination theory (Order No. 10250708). Available from ProQuest Dissertations \& Theses Global. (1886113856). Retrieved from https://searchproquest-com.berlioz.brandonu.ca/docview/1886113856? accountid=9705

Brown, M. M. (2002). An exploratory study of job satisfaction and work motivation of a select group of information technology consultants in the Delaware valley (Order No. 3041882). Available from ProQuest Dissertations \& Theses Global. (305443787). Retrieved from https://search-proquestcom.berlioz.brandonu.ca/docview/305443787?accountid $=9705$

Bundschuh, A. L., Jr. (2018). Relationships between project cost, project team member role, project schedule, and burnout (Order No. 10822903). Available from ProQuest Dissertations \& Theses Global. (2046948196). Retrieved from https://search-proquestcom.berlioz.brandonu.ca/docview/2046948196?accountid=9705

Campbell, J.P. (1990). Modeling the performance prediction problem in industrial and organizational psychology. In M.D. Dunnette \& L.M. Hough (Eds.) Handbook of Industrial and Organizational Psychology, 1: 687-732, Palo Alto, CA: Consulting Psychologists Press

Cerasoli, C.P., Nicklin, J.M., \& Ford, M.T. (2014). Intrinsic motivation and extrinsic incentives jointly predict performance: A 40 year meta-analysis. Psychological Bulletin,140(4), 9801008 http://dx.doi.org/10.1037/a0035661

Chen,Y-L.,\& Fouad,N.A.(2016). Bicultural work motivation scale for Asian American college students. International Journal for Educational and Vocational Guidance. 16(2):275-297

Cherns, A.B. (1976).The principles of Organizational design. Human Relations, 29(8): 783-792, https://doi.org/10.1177/001872677602900806

Chiu, S. (2005). The linkage of job performance to goal setting, work motivation, team building, and organizational commitment in the high -tech industry in Taiwan (Order No. 3158664). Available from ProQuest Dissertations \& Theses Global. (305354658).

Retrieved from https://search-proquestcom.berlioz.brandonu.ca/docview/305354658? accountid $=9705$

Cornella, K. A. (1992). The effects of employee involvement and high-involvement gainsharing on job satisfaction, organizational commitment and intrinsic motivation (Order No. 9316894). Available from ProQuest Dissertations \& Theses Global. (304066520).

Retrieved from https://search-proquestcom.berlioz.brandonu.ca/docview/304066520?accountid=9705 
Davis, C. J. (1995). Communicating shared vision in a scientific research organization (Order No. 9543566). Available from ProQuest Dissertations \& Theses Global. (304197301). Retrieved from https://search-proquestcom.berlioz.brandonu.ca/docview/304197301 ?accountid $=9705$

Dunbar, S. B. (2002). Perceived work motivation factors among allied health managers and subordinates (Order No. 3058553). Available from ProQuest Dissertations \& Theses Global. (305469091). Retrieved from https://search-proquestcom.berlioz.brandonu.ca/docview/305469091 accountid $=9705$

Dunbar, S. E. (2017). Exploring the relationship of burnout, retention, and tenure between fulltime professors teaching in a traditional brick and-mortar environment and full-time professors teaching in a fully online environment (Order No. 10743985). Available from ProQuest Dissertations \& Theses Global. (2021979444). Retrieved from https://searchproquest-com.berlioz.brandonu.ca/docview/2021979444? accountid=9705

Dwivedula, R., Bredillet, C., Müller, R. (2018). Work Motivation in Temporary Organizations: Establishing Theoretical Corpus. Management and Organizational Studies. 5(3): 29-42, DOI. 10.5430/mos.v5n3p29

Emelander, S. J. (2011). A study of burnout and intrinsic needs fulfillment among project managers (Order No. 3443317). Available from ProQuest Dissertations \& Theses Global. (854846638). Retrieved from https://search-proquestcom.berlioz.brandonu.ca/docview/854846638?

Evans, D. (2018). The role of job attitudes on knowledge sharing in cross-functional IT project teams: A qualitative study (Order No. 10748293). Available from ProQuest Dissertations $\&$ Theses Global. (2027819160). Retrieved from https://search-proquestcom.berlioz.brandonu.ca/docview/2027819160?accountid=9705

Frahm, V. L. (2015). Mediating role of task strategies and project stability in the relationship between project complexity and team transactive memory system (TMS) (Order No. 3689229). Available from ProQuest Dissertations \& Theses Global. (1675961265). Retrieved from https://search-proquestcom.berlioz.brandonu.ca/docview/1675961265?accountid=9705

Gagné, M. et al.(2015). The multidimensional work motivation scale: Validation evidence in seven languages and nine countries. European Journal of Work and Organizational Psychology. 24:2,178-196,DOI:10.1080/1359432X.2013.877892

Gallaway, R. A. (2015). Perceptions of information technology specialists regarding securing reemployment after offshoring displacement (Order No. 10012364). Available from ProQuest Dissertations \& Theses Global. (1766119095). Retrieved from https://searchproquest-com.berlioz.brandonu.ca/docview/1766119095?accountid=9705

Hardré, P.L. (2003). Beyond two decades of motivation: A review of research and practice in instructional design and human performance technology. Human Resource Development Review. 2(1): 54-81, DOI: 10.1177/1534484303251661

Heimgartner, R., Windl, H. \& Solanki, A. (2011) The Necessity of Personal Freedom to Increase HCI Design Quality. In: Marcus, A., Ed., Design, User Experience, and Usability, Theory, Methods, Tools and Practice (DUXU 2011), Springer, Berlin, 62-68; https://doi.org/10.1007/978-3-642-21675-6_7

Hensler, V. F. (1987). The Relationship Of Personal Incentives, Job Opportunity Incentives, And Performance For Real Estate Associates (Order No. 8721655). Available from ProQuest Dissertations \& Theses Global. (303590487). Retrieved from https://search-proquest- 
com.berlioz.brandonu.ca/docview/303590487?accountid=9705

Hernick, R. M. (2017). Assessing the relationships between the intrinsic factors of selfdetermination theory for motivation and job satisfaction factors (Order No. 10635782). Available from ProQuest Dissertations \& Theses Global. (1972042709). Retrieved from https://search-proquest-com.berlioz.brandonu.ca/docview/1972042709?accountid=9705

Herzberg, F., Mausner, B., \& Snyderman, B.B. (1959).The Motivation to Work, NY: John Wiley Hillebrand, J. (2014). Employer expectations of bachelor-level business graduates in United Arab Emirates: A Delphi study (Order No. 3691410). Available from ProQuest Dissertations \& Theses Global. (1668318463). Retrieved from https://search-proquestcom.berlioz.brandonu.ca/docview/1668318463?accountid=9705

Holden, A. D. (2002). A study of the relationship between participation in employer -provided professional development programs and project managers' intrinsic motivation, job satisfaction and organizational commitment (Order No. 3041815). Available from ProQuest Dissertations \& Theses Global. (305444840). Retrieved from https://searchproquest-com.berlioz.brandonu.ca/docview/305444840? accountid $=9705$

Jaffee, D. L. (2015). The reward preferences of mid-level student affairs professionals and the influence on job performance perceived by these individuals (Order No. 3737725). Available from ProQuest Dissertations \& Theses Global. (1748050911). Retrieved from https://search-proquest-com.berlioz.brandonu.ca/docview/1748050911?accountid=9705

Janke,S.,Daumiller,M.,\& Rudent,S.C.(2018). Dark pathways to achievement in scienceResearcher's achievement goals predict engagement in questionable research practices. Social psychological and personality science, 1-9. https://doi.org/10.1177/1948550618790227

Johnson, N., Creasy, T., \& Fan, Y. (2016). Recent Trends in Theory Use and Application within the Project Management Discipline. Journal of Engineering, Project, and Production Management, 6(1):25-52

Kanfer, R. (1990). Motivation theory and industrial/organizational psychology. In M.D. Dunnette and L. Hough (Eds.), Handbook of industrial and organizational psychology. Vol 1. Theory in industrial and organizational psychology (pp.75-170), Palo Alto, CA: Consulting Psychologists Press

Kanfer,R.(2010). Work motivation: Theory, practice, and future directions. In S.W. Kozlowski (Ed.) The Oxford hand book of industrial and organizational Psychology. DOI: 10.1093/oxfordhb/9780199928309.013.0014

Kea, H. E. (2008). How are NASA engineers motivated? an analysis of factors that influence NASA Goddard engineers' level of motivation (Order No. 3340862). Available from ProQuest Dissertations \& Theses Global. (288416135). Retrieved from https://searchproquest-com.berlioz.brandonu.ca/docview/288416135?accountid=9705

Kluger, A.N., \& DeNisi, A. (1996). The effects of feedback interventions on performance: Historical review, a meta-analysis and a preliminary feedback intervention theory. Psychological Bulletin, 119: 254-284 http://dx.doi.org/10.1037/0033-2909.119.2.254

Leung, M-Y., Chan, Y.S. ,\& Dondyu, C. (2011). Structural linear relationships between job stress, burnout, physiological stress, and performance of construction project managers. Engineering, Construction and Architectural Management, 18(3): 312-328; https://doi.org/10.1108/09699981111126205

Lidner, F., \& Wald,A.(2011). Success factors of knowledge management in temporary organizations. International Journal of Project Management. 29(7):877-888, 
DOI:10.1016/j.ijproman.2010.09.003

Mahoney, R.C., \& Lederer, A.L. (2006).The effect of intrinsic and extrinsic rewards for developers on information systems project success. Project Management Journal, 37(4): 42-55; https://doi.org/10.1177/875697280603700405

Mirza, S. (2005). Job satisfaction among research and development scientists: The relationship of leadership practices and job characteristics (Order No. 3178467). Available from ProQuest Dissertations \& Theses Global. (305351764). Retrieved from https://searchproquest-com.berlioz.brandonu.ca/docview/305351764?accountid=9705

Moody, A. (2008). Examining and exploring generational differences by understanding commitment, employee satisfaction, and motivation (Order No. 3298966). Available from ProQuest Dissertations \& Theses Global. (304822447). Retrieved from https://searchproquest-com.berlioz.brandonu.ca/docview/304822447? accountid $=9705$

Moore, T. G., Jr. (2007). Virtual team member motivation in new product development: An investigation into the influence of leadership behaviors (Order No. 3274080). Available from ProQuest Dissertations \& Theses Global. (304721548). Retrieved from https://search-proquest-com.berlioz.brandonu.ca/docview/304721548?accountid=9705

Morgeson, F., \& Humphrey, S. (2006). The work design questionnaire (WQQ): Developing and validating a comprehensive measure for assessing job design and the nature of work. Journal of Applied Psychology, 91: 1321-1399; DOI: 10.1037/0021-9010.91.6.132

Müller, R., \& Turner, R. (2010). Leadership competency profiles of successful project managers. International Journal of Project Management, 28: 437-448

Nesheim, T.,\& Smith, J.( 2015). Knowledge sharing in projects: Does employment arrangement matter?, Personnel Review, 44(2): 255-269; https://doi.org/10.1108/PR-11-2013-0203

Parker, S.K., Broeck, A.V.D., \& Holman, D. (2017). Work Design Influences: Synthesis of Multilevel Factors that Affect the Design of Jobs. Academy of Management Annals, 11(1): 267-308. DOI.10.5465/annals.2014.0054

Paul, W.J.Jr., Robertson, K.B., \& Herzberg, F. 1969. Job enrichment pays off, MA:Harvard Business Press

Perreira, T. A. (2016). Insights into nurses' work: Exploring relationships among work attitudes \& work-related behaviours (Order No. 10043967). Available from ProQuest Dissertations \& Theses Global. (1775742289). Retrieved from https://search-proquestcom.berlioz.brandonu.ca/docview/1775742289?accountid=9705

Pitron, J. E. (2008). The influence of exemplary followership on organizational performance: A phenomenological approach (Order No. 3302640). Available from ProQuest Dissertations \& Theses Global. (304309327). Retrieved from https://search-proquestcom.berlioz.brandonu.ca/docview/304309327?accountid $=9705$

Prior, Y. (2015). Investigating extrinsic and intrinsic employee needs in hospitality workers (Order No. 3733853). Available from ProQuest Dissertations \& Theses Global. (1746624236). Retrieved from https://search-proquestcom.berlioz.brandonu.ca/docview/1746624236? accountid=9705

Procaccino,D.J.,\& Verner,J.M.(2006).Software project managers and project success: An exploratory study. The Journal of Systems and Software, 79: 1541-1551, doi:10.1016/j.jss.2006.01.010

Remmel, A. M. (2002). Trust, leadership, and organizational renewal (Order No. NQ69260). Available from ProQuest Dissertations \& Theses Global. (305453573). Retrieved from https://search-proquest-com.berlioz.brandonu.ca/docview/305453573?accountid=9705 
Ricotta, A. G. (2018). Motivation strategies for improving consistency in live-entertainment employees' performances (Order No. 10829292). Available from ProQuest Dissertations \& Theses Global. (2059826491). Retrieved from https://search-proquestcom.berlioz.brandonu.ca/docview/2059826491?accountid=9705

Rose, T.M., \& Manley, K. (2010). Motivation toward financial incentive goals on construction projects. Journal of Business Research, 64(7): 765-773; https://doi.org/10.1016/j.jbusres.2010.07.003

Ryan, J.C. (2011). Development of a measure of work motivation for a meta-theory of motivation. Psychological Reports. 103, 3, 743-755, https://doi.org/10.2466/01.14.20.PR0.108.3.743-755

Sasala, R. L. (2014). The role of organizational leaders in the motivation of high performers (Order No. 3624842). Available from ProQuest Dissertations \& Theses Global. (1554346137). Retrieved from https://search-proquestcom.berlioz.brandonu.ca/docview/1554346137?accountid=9705

Schmid, B., \& Adams, J. (2008). Motivation in project management: The project manager's perspective. Project Management Journal, 39(2): 60-71; DOI: $10.1002 / \mathrm{pmj} .20042$

Schwartz, M. L. (2013). An investigation to determine the effectiveness of motivating strategies leaders might employ to increase followers' effort in the workplace (Order No. 3589631). Available from ProQuest Dissertations \& Theses Global. (1430500743). Retrieved from https://search-proquest-com.berlioz.brandonu.ca/docview/1430500743?accountid=9705

Seiler,S.,Bogdan,L.,Pinkowska,M., \& Pinnazza,M.(2011). An integrated model of factors influencing project managers' motivation-Findings from a Swiss survey. International Journal of Project Management. 30(1):6072.https://doi.org/10.1016/j.ijproman.2011.03.002

Shahir,M.I.,Phulpoto,N.H.,\& Zafar,U. (2018). Impact of intrinsic factors of motivation on employee's intention to leave. New Horizons, 12(1): 99-112, DOI:DOI:10.2.9270/NH.12.2(18).0

Sieler, S., Lent, B., Pinkowska, M., \& Pinazza, M. (2012). An integrated model of factors influencing project managers' motivation-Findings from a Swiss Survey. International Journal of Project Management, 30(1):60-72, DOI:10.1016/j.ijproman.2011.03.002

Smith, S. (2012). Qualitative perspectives of factors influencing community college students' stated motivation to enroll in future foreign language programs (Order No. 3607960). Available from ProQuest Dissertations \& Theses Global. (1496775064). Retrieved from https://search-proquest-com.berlioz.brandonu.ca/docview/1496775064?accountid=9705

Steenkamp, D. H. (2014). Project teams: The relationship between motivation and communication as experienced by it and business members (Order No. 3646105). Available from ProQuest Dissertations \& Theses Global. (1629468996). Retrieved from https://search-proquest-com.berlioz.brandonu.ca/docview/1629468996?accountid=9705

Steers, R.M., Mowday, R.T. and Shapiro, D.L. (2004) Introduction to Special Topic Forum: The Future of Job Motivation Theory. The Academy of Management Review, 29, 379-387

Stewart, T. I. (1980). A study of factors affecting the development of a general contingency theory of management macroethics. (Order No. 8012750). Available from ProQuest Dissertations \& Theses Global. (287998338). Retrieved from https://search-proquestcom.berlioz.brandonu.ca/docview/287998338?accountid=9705

Tankoonsombut, K. (1998). Investigation of the effects of feedback and goal -setting on 
knowledge work performance in the distributed work environment (Order No. 3119706). Available from ProQuest Dissertations \& Theses Global. (304452902). Retrieved from https://search-proquest-com.berlioz.brandonu.ca/docview/304452902?accountid=9705

Taylor, F.W. (1911). The principles of scientific management, New York: Harper

Thy-Jensen,U.,\& Ladegaard,L.(2017). How transformational leadership supports intrinsic motivation and public service motivation: The mediating role of basic need satisfaction. The American Review of Public Administration, 48(6): 538-549, https://doi.org/10.1177/0275074017699470.

Tonial, J. C. (2009). Examining the relationship between perceived technical competency and intrinsic motivation for information technology managers (Order No. 3388320). Available from ProQuest Dissertations \& Theses Global. (305121346). Retrieved from https://search-proquest-com.berlioz.brandonu.ca/docview/305121346?accountid=9705

Toode, K.,Routasalo,P.,\& Souminen,T.(2011).Work motivation of nurses: A literature review. International Journal of Nursing Studies. 48(2): 246-257, DOI:10.1016/j.ijnurstu.2010.09.013

Trist, E., \& Bamforth, W. (1951). Some social and psychological consequences of the long wall method of coal getting. Human Relations, 4, 3-38; https://doi.org/10.1177/001872675100400101

Turner, R., \& Lloyd-Walker, B. (2008). Emotional Intelligence (EI) capabilities training: Can it develop EI in project teams? International Journal of Managing Projects in Business, 1(4):512-534, https://doi.org/10.1108/17538370810906237

Wagner, J. C. (1974). Relationships Between Personal Needs And Performance Ratings Of Educational Project Managers (Order No. 7424420). Available from ProQuest Dissertations \& Theses Global. (302697015). Retrieved from https://search-proquestcom.berlioz.brandonu.ca/docview/302697015?accountid $=9705$

Walker, C.R., \& Guest, H. (1952). The man on the assembly line, Cambridge, MA: Harvard University Press

Wheeler, C. J. (1999). Principals' views of how they motivate their teachers (Order No. MQ47150). Available from ProQuest Dissertations \& Theses Global. (304544440). Retrieved from https://search-proquestcom.berlioz.brandonu.ca/docview/304544440?accountid $=9705$

Whisler, R. D. (2014). The antecedents of burnout in the profession of information technology support (Order No. 3662861). Available from ProQuest Dissertations \& Theses Global. (1685000301). Retrieved from https://search-proquestcom.berlioz.brandonu.ca/docview/1685000301?accountid=9705

Williams, A. (2017). Sustainability strategies for small business restaurant owners (Order No. 10681640). Available from ProQuest Dissertations \& Theses Global. (1972895708). Retrieved from https://search-proquestcom.berlioz.brandonu.ca/docview/1972895708?accountid=9705

Willis, K. M. (2001). Identifying the critical success factors in formal mentoring systems: An analysis of the Lehigh Portland cement mentoring program (Order No. MQ59515). Available from ProQuest Dissertations \& Theses Global. (304777648). Retrieved from https://search-proquest-com.berlioz.brandonu.ca/docview/304777648?accountid=9705 